\title{
TABLET FORMULATIONS OF VIABLE LACTIC ACID BACTERIA
}

\author{
M. Stadler and H. Viernstein* \\ Institute of Pharmaceutical Technology and Biopharmaceutics, University of Vienna, Althanstraße \\ 14, A-1090, Vienna, Austria
}

\begin{abstract}
Summary
The aim of this work was to develop a gastric juice-resistant tablet formulation of viable lactic acid bacteria (LAB). As excipients, hydroxypropyl-methylcellulose acetate succinate (HPMCAS) and sodium alginate were applied to enhance gastric juice-resistance, andAvicel ${ }^{\circledR}$ was used to modify tablet disintegration in the intestine. The formulation was optimized using statistical experimental design methodology. The influence of the relevant process variables (amounts of excipients applied and compaction force) on the loss of viable cells during the tablet production, on acid stability, and on tablet disintegration time was investigated. It was found that the content of HPMCAS and the compaction force were the most important test variables for tablet preparation. They influence the loss of bacteria during the tableting process, gastric juice resistance, and the disintegration time of tablets after incubation in artificial intestinal fluid. Avicel ${ }^{\otimes}$ had little influence on all three test parameters, while sodium alginate only affected disintegration time in phosphate buffer $\mathrm{pH} 6.8$.
\end{abstract}

Keywords: lactic acid bacteria, matrix tablets

\section{Introduction}

Lactic acid bacteria (LAB) are a heterogeneous group of gram-positive rods and cocci that use carbohydrates as an energy source and produce lactic acid either as the sole product of metabolism or as the major end product. LAB present in the human and animal gut are introduced through fermented milk products, food and feed supplements, but also through pharmaceutical products ${ }^{1}$. $\mathrm{LAB}$ have been used to promote health for hundreds of years; their most obvious effect is the inhibition of pathogen growth in traditionally fermented food systems, accomplished primarily by the acidic nature of these cultures ${ }^{2}$. Stated health-promoting effects of LAB include improved absorption of nutrients, alleviation of lactose intolerance symptoms, metabolism of some drugs, reduction of serum cholesterol, decrease of enzymes implicated in carcinogen production, improvement of intestinal motility, stimulation of the immune system, and reduction of tumor incidence.

The harmful effects of undesired bacteria can be overcome by establishing a new balance among the intestinal flora through ingestion of viable bacteria ${ }^{3}$. For a successful implantation in the gastrointestinal tract, it is essential that bacteria survive stomach acidity. Due to the instability of $\mathrm{LAB}$ towards acid, they require protection during transit through the stomach.

One possibility to avoid deterioration is incorporation of lyophilized LAB in lipophilic matrices ${ }^{4}$ or coatings with fat or fat like materials ${ }^{5}$. Furthermore, mixtures of LAB and buffer substances, which raise the $\mathrm{pH}$ value of the gastric medium for a few hours after application, should facilitate the transit of viable bacteria from the stomach to the intestine ${ }^{6}$. Moreover, as in the present study bacteria can be embedded in acid resistant excipients, such as HPMCAS, by direct compression. 


\section{Experimental}

Lyophilized LAB strain Lactobacillus acidophilus La-5 $\left(2.0 \times 10^{11} \mathrm{CFU} / \mathrm{g}\right)$ was supplied from Chr. Hansen BioSystems (Horsholm, Denmark), HPMCAS was purchased from Shin-Etsu Chemicals Ltd. (Tokyo, Japan), sodium alginate and Avicel $^{\circledR}$ from Fluka (Buchs, Switzerland).

Microbial cell count determinations were done according to the Koch plate count technique ${ }^{7}$ using Rogosa Agar $^{8}$ from Merck (Darmstadt, Germany).

Tablet processing was performed on an instrumented single punch tablet press (Korsch EKO, Berlin, Germany), under constant environmental conditions (35\% R.H.; 20-22 ${ }^{\circ}$ C). Tablets were prepared biplan with a diameter of $10 \mathrm{~mm}$.

The loss of bacteria due to the tableting process was determined by calculation from numbers of viable cells in the mixed powders prior to compaction and in the tablets made therefrom.

Artificial gastric juice $(0.04 \mathrm{~N} \mathrm{HCl})$ was used to evaluate the survival of LAB under acidic conditions using a dissolution tester (USP XXIV). For evaluation of the gastric juice resistance, tablets were incubated in $0.04 \mathrm{~N} \mathrm{HCl}$ at $37^{\circ} \mathrm{C}$ for two hours, and the differences were determined of the microbial cell counts before and after treatment.

Tablet disintegration time in intestinal fluid was studied by incubation in phosphate buffer ( $\mathrm{pH}$ 6.8) using a dissolution tester (USP XXIV).

An orthogonal central composite design ${ }^{9}$ was created to study the main effects and interactions of four factors on the loss of viable bacteria during tableting, on gastric juice-resistance, and on the disintegration time in the intestinal fluid. The factors investigated were the compaction force, and the contents of HPMCAS, Avicel, ${ }^{\circledR}$ and sodium alginate. Twenty seven experiments were required and the combinations were performed in random orders (Table 2). The dry weight of freeze dried bacteria was kept constant at $100 \mathrm{mg}\left(3 \times 10^{10} \mathrm{CFU}\right)$ per tablet. Sixteen runs represent the simple factorial design, and 8 the star points; the centre points were replicated three times. The axial distance $(\alpha)$ of the star points was 1.547 .

The independent variables and their experimental settings are listed in Table 1.

Table 1: Factors and levels investigated for tablet formulations of the orthogonal central composite design (formulations No. 1-27)

\begin{tabular}{cccccc}
\hline Factor & $\begin{array}{c}\text { star } \\
(-\alpha)\end{array}$ & $\begin{array}{c}\text { Tow } \\
(-1)\end{array}$ & $\begin{array}{c}\text { center } \\
(0)\end{array}$ & $\begin{array}{c}\text { high } \\
(+1)\end{array}$ & $\begin{array}{c}\text { star } \\
(+\alpha)\end{array}$ \\
\hline $\begin{array}{c}\text { compaction- } \\
\text { force }(\mathrm{kN}) \\
\mathrm{HPMC} \\
(\mathrm{mg})\end{array}$ & 4.5 & 10 & 20 & 30 & 35.5 \\
$\begin{array}{c}\text { Na-alginate } \\
(\mathrm{mg})\end{array}$ & 3.4 & 7.5 & 15 & 22.5 & 26.6 \\
$\begin{array}{c}\text { Avicel } \\
\text { (m) }\end{array}$ & 6.8 & 15 & 30 & 40 & 53.2 \\
\hline
\end{tabular}

Data analysis of the experimental design was performed using Statgraphics Plus for Windows 2.0 (Manugistics, Rockville, MD). 
Table 2: Experimental settings and results of the central composite design

\begin{tabular}{ccccccc}
\hline kN & $\begin{array}{c}\text { HPMC } \\
\text { (mg) }\end{array}$ & $\begin{array}{c}\text { Na- } \\
\text { alg. } \\
(\mathrm{mg})\end{array}$ & $\begin{array}{c}\text { Avice } \\
(\mathrm{mg})\end{array}$ & tabl. & $2 \mathrm{~h}$ & hours \\
\hline 20 & 200 & 15 & 30 & 1.02 & 0.13 & 6.0 \\
10 & 125 & 7.5 & 15 & 0.44 & 0.83 & 2.5 \\
30 & 125 & 7.5 & 15 & 1.04 & 0.32 & 2.75 \\
10 & 275 & 7.5 & 15 & 0.82 & 0.32 & 6.0 \\
30 & 275 & 7.5 & 15 & 1.13 & 0.12 & 7.5 \\
10 & 125 & 22.5 & 15 & 0.38 & 0.88 & 3.0 \\
30 & 125 & 22.5 & 15 & 1.00 & 0.31 & 3.5 \\
10 & 275 & 22.5 & 15 & 0.85 & 0.37 & 8.0 \\
30 & 275 & 22.5 & 15 & 1.18 & 0.13 & 8.75 \\
10 & 125 & 7.5 & 45 & 0.63 & 0.66 & 3.0 \\
30 & 125 & 7.5 & 45 & 1.30 & 0.10 & 3.25 \\
10 & 275 & 7.5 & 45 & 0.83 & 0.34 & 7.25 \\
30 & 275 & 7.5 & 45 & 1.14 & 0.14 & 8.25 \\
20 & 200 & 15 & 30 & 1.00 & 0.13 & 6.25 \\
10 & 125 & 22.5 & 45 & 0.75 & 0.60 & 3.5 \\
30 & 125 & 22.5 & 45 & 1.34 & 0.06 & 4.75 \\
10 & 275 & 22.5 & 45 & 0.81 & 0.33 & 7.75 \\
30 & 275 & 22.5 & 45 & 1.15 & 0.14 & 9.5 \\
4.5 & 200 & 15 & 30 & 0.16 & 0.91 & 4.0 \\
35.5 & 200 & 15 & 30 & 1.10 & 0.08 & 6.25 \\
20 & 83.9 & 15 & 30 & 0.74 & 0.63 & 2.75 \\
20 & 316 & 15 & 30 & 1.03 & 0.10 & 9.0 \\
20 & 200 & 3.4 & 30 & 1.06 & 0.08 & 5.75 \\
20 & 200 & 26.6 & 30 & 1.08 & 0.11 & 7.5 \\
20 & 200 & 15 & 6.8 & 1.01 & 0.12 & 6.0 \\
20 & 200 & 15 & 53.2 & 1.03 & 0.12 & 5.75 \\
20 & 200 & 15 & 30 & 1.03 & 0.16 & 5.75 \\
\hline \hline
\end{tabular}

No........ formulation number

$\mathrm{kN}$........ compaction force during the tableting process

Na-alg... sodium alginate

tabl........ microbial cell count decrease during tableting (log units)

$2 \mathrm{~h}$......... microbial cell count decrease during incubation in $0.04 \mathrm{~N}$ for $2 \mathrm{~h}$ (log units)

hours.... disintegration time in the intestinal fluid (hours)

\section{Results and Discussion}

\section{Loss of viable bacteria due to tableting}

As shown by the analysis of the central composite design, the loss of viable bacteria was dependent on the compaction force. HPMCAS and Avicel ${ }^{\circledR}$, but independent of the content of sodium alginate. The compaction force had the greatest influence: the loss of viable cells was least when a low compaction force was applied. Upon raising of the compaction force from 10 to $30 \mathrm{kN}$. microbial cell count reduction reaches a maximum. Results suggest that an extremely high compaction force of $35.5 \mathrm{kN}$ leads to a similar cell count reduction as a compaction force of $30 \mathrm{kN}$. The loss of viable cells was also smaller applying a smaller content of HPMCAS. The content of HPMCAS had no influence when a high compaction force was used. The microbial cell count reduction also decreased by lowering the content of Avicel ${ }^{\circledR}$.

Influences of the relevant factors on the loss of bacteria due to tableting are shown in Figure 1 
Figure 1: Microbial cell count reduction caused by tableting - main effects of the relevant factors (C: force: compaction force)

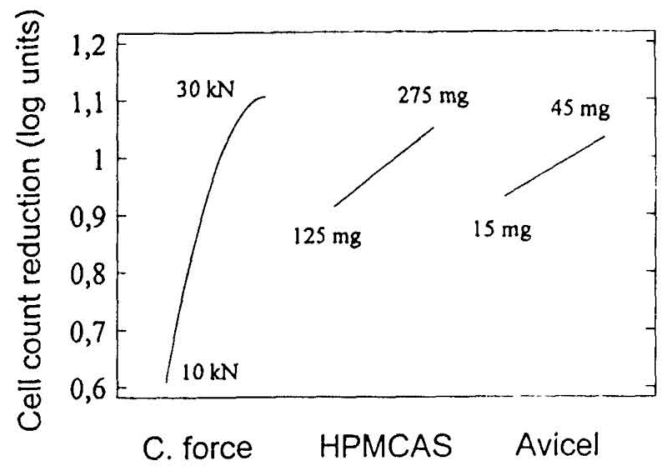

Interactions of the factors HPMCAS and compaction force are illustrated in Figure 2. This figure shows the microbial cell count reductions observed when tablets were prepared by a compaction force between $10 \mathrm{kN}$ and $30 \mathrm{kN}$, with a content of HPMCAS between $120 \mathrm{mg}$ and $275 \mathrm{mg}$. Tablets manufactured with a compaction force of $30 \mathrm{kN}$ and with a high HPMCAS content show the highest loss of viable cells during the tableting process.

Figure 2: Response surface plot for the effects of the compaction force and the amounts of HPMCAS on the loss of viable bacteria during tablet production

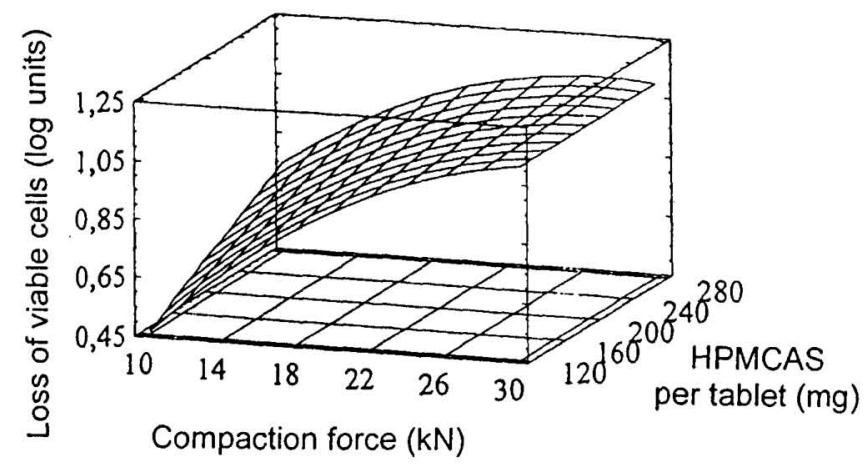




\section{Gastric juice resistance}

Gastric juice resistance of the formulations was higher, when tablets had been prepared with a high compaction force or a medium/high amount of HPMCAS. The results of the orthogonal design suggest that the use of compaction forces between $30 \mathrm{kN}$ and $35.5 \mathrm{kN}$ or HPMCAS contents between $275 \mathrm{mg}$ and $316 \mathrm{mg}$ per tablet result in similar microbial cell count decreases, showing that extremely high settings of these two variables are not essential for reaching good gastric juiceresistance.

Avicel $^{\circledast}$ content had only little influence, while sodium alginate did not affect the survival rate of the bacteria during the simulated transit through the stomach. Figure 3 shows the main effects of the factors investigated.

Figure 3: Microbial cell count reduction caused by incubation in artificial gastric juice - main effects of the relevant factors (C. force: compaction force)

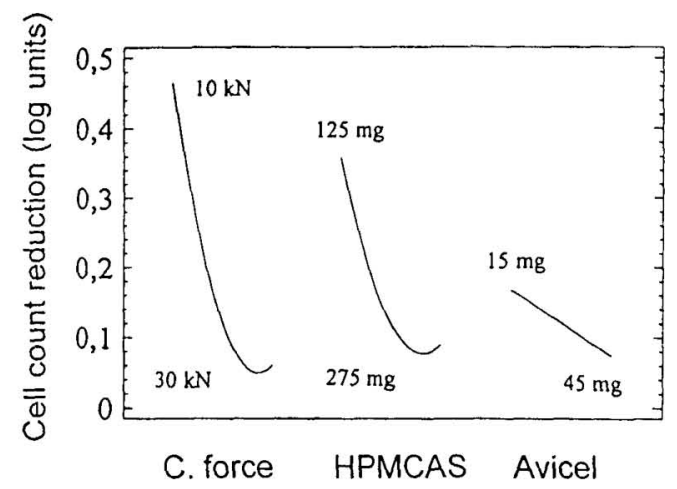

As shown in Figure 4, gastric juice-resistance was determined of tablets manufactured by a compaction force between $10 \mathrm{kN}$ and $30 \mathrm{kN}$, applying amounts of HPMCAS between $120 \mathrm{mg}$ and $280 \mathrm{mg}$ per tablet. Formulations prepared with high compaction forces $(>20 \mathrm{kN})$ applying high amounts of HPMCAS ( $>200 \mathrm{mg}$ ) show the slightest loss of viable cells during incubation in $0.04 \mathrm{~N}$ $\mathrm{HCl}$ (less than $0.2 \mathrm{log}$ units after incubation for two hours).

In summary of the results presented so far, the effects of the experimental factors, compaction force and content of HPMCAS on the loss of viable bacteria due to tableting, and on the loss during incubation in gastric juice were opposite, suggesting that comparable counts of viable bacteria, from $0,7 \times$ to $2,0 \times 10^{9}$, as determined in vitro, would reach the intestine after administration of a tablet irrespective of the experimental settings for tablet preparation: tablets containing high amounts of HPMCAS and compacted by high compaction forces showed the best gastric juice resistance, but the highest loss of viable bacteria during tablet preparation. Tablets prepared by application of low compaction forces, with low contents of HPMCAS showed the smallest loss of viable cells during tableting, but the highest loss of viable cells during simulated gastric transit.

Therefore, the disintegration time in artificial intestinal fluid is a variable of considerable interest. 
Figure 4: Response surface plot for the effects of the compaction force and the content of HPMCAS on resistance to gastric juice

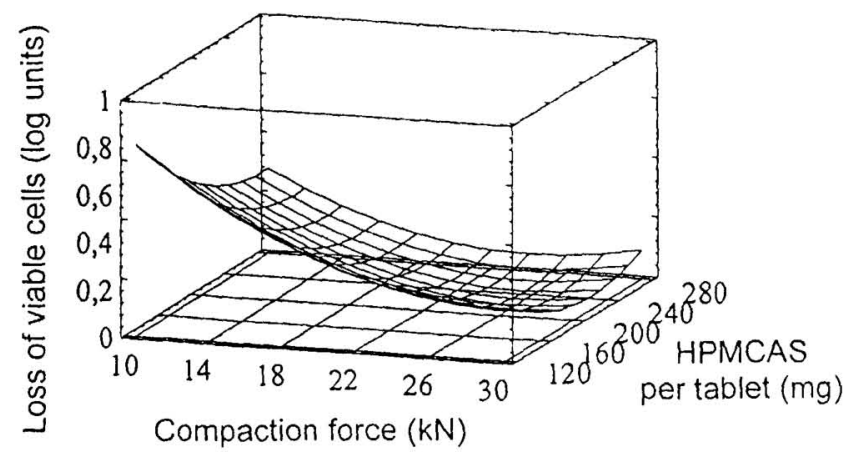

\section{Disintegration time in artificial intestinal fluid}

Each parameter influenced the disintegration time in the intestinal fluid, but no interactions were observed between the parameters investigated.

Fast disintegration in phosphate buffer was preferred and was achieved when tablets were manufactured applying a low compaction force and low amounts of HPMCAS, sodium alginate and Avicel ${ }^{\circledR}$ as shown in Figure 5. Avicel ${ }^{\circledR}$, originally used to accelerate disintegration time, surprisingly also delays tablet disintegration in the intestinal fluid.

Figure 5: Tablet disintegration time - main effects of the parameters investigated (C. force: compaction force; Algin.: sodium alginate)

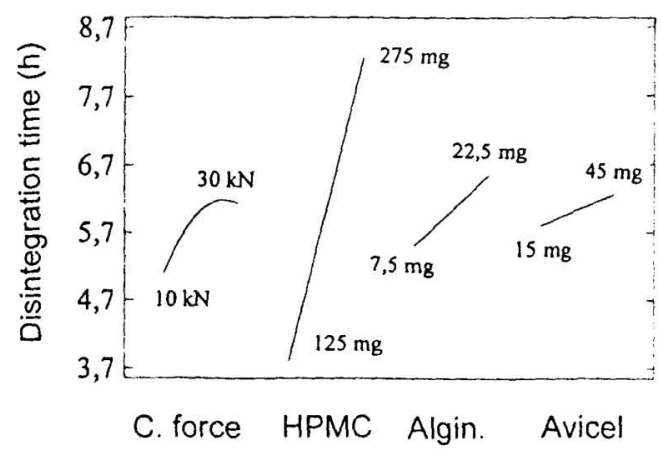


M. St adler and H. Viernst e i n: Tablet Formulations of Viable Lactic Acid ... 255

The content of HPMCAS in the tablets had the greatest influence on this test parameter. Tablets prepared with HPMCAS amounts of $275 \mathrm{mg}$ disintegrated after only eight hours. Formulation No. 22 , compacted with the highest amount of HPMCAS of all formulations examined had the longest disintegration time, while formulation No. 2 (containing low amounts of HPMCAS) disintegrated within 2.5 hours.

\section{References}

1. Fernandes C.F., Shahani K.M., Amer M.A. (1987), FEMS Microbiol. Rev. 46: 343

2. Sanders M.E. (1993), Advanced in Food and Nutrition Research 37: 67

3. Berrada N., Lemeland J.F., Laroche G., Thouvenot P., Piaia M, (1990), J. Dairy Sci. 74: 409

4. Kneifel W., Viernstein H., Raffalt J. (1996), PCT/ AT96/00212

5. Viernstein H. (2000), AT001230 U1

6. Viernstein H. (1998), AT 1360/98 A61K

7. Mersch-Sundermann V. (1989), Medizinische Mikrobiologie. Georg Thieme, Stuttgart

8. Rogosa M., Mitchell J.A., Wiseman R.F. (1951), J. Appl. Bacteriol. 62: 132

9. Luftensteiner C.P., Viernstein H. (1998), Int. J. Pharm. 171: 87

Dedicated with best wishes to o.Univ.-Prof. Dr. W. Fleischhacker on the occasion of his $70^{\text {th }}$ birthday. 